\title{
Effect of drying method and irradiation on the microbiological quality of moringa leaves
}

\author{
Abraham Adu-Gyamfi, Tahiru Mahami \\ Biotechnology and Nuclear Agriculture Research Institute, Ghana Atomic Energy Commission, P.O. Box LG 80, Accra Legon, Ghana \\ Email address: \\ adugyamfi21@yahoo.com (A. Adu-Gyamfi),teem2002gh@yahoo.com(T. Mahami)
}

To cite this article:

Abraham Adu-Gyamfi, Tahiru Mahami. Effect of Drying Method and Irradiation on the Microbiological Quality of Moringa Leaves. International Journal of Nutrition and Food Sciences. Vol. 3, No. 2, 2014, pp. 91-96. doi: 10.11648/j.ijnfs.20140302.21

\begin{abstract}
Effect of drying method and irradiation on the microbiological quality of dried moringa leaves (DML) was investigated. Moringa leaves dried by 3 methods (mechanical, solar and room drying) was assessed for microbiological quality in addition to 6 different retail samples of DML. Mechanical, solar and room-dried moringa leaves were irradiated at doses of $0,2.5,5.0,7.5,10.0 \mathrm{kGy}$ with gamma radiation from a Co-60 source and the microbiological quality was assessed using the methods of serial dilution and pour plating. Range of mean counts of total viable cells, coliforms, moulds and yeasts, E. coli and Pseudomonas spp. of the retail samples of DML were respectively 5.92 - 8.44, 4.85 - 7.25, $1.65-3.69,3.71-4.78$ and $1.84-4.22 \log _{10} \mathrm{cfu} / \mathrm{g}$. Salmonella spp. was detected in 2 out of the 6 retail samples analysed. Room-dried moringa leaves relatively had high counts of total viable cells (6.45); coliforms (6.18); moulds and yeasts (3.46); E. coli (1.58) and Pseudomonas spp. (3.32) compared to samples dried by mechanical or solar methods. Irradiation dose of $2.5 \mathrm{kGy}$ reduced the counts of all microorganisms to $\leq 3.57$ and no survivors were detected in the samples of DML at 5, 7.5 and $10 \mathrm{kGy}$. High counts of total viable cells, coliforms, E. coli, Pseudomonas spp. and presence of Salmonella spp. in retail samples of DML raise food safety concerns. Solar-dried moringa leaves had improved microbiological quality compared to mechanical or room-dried leaves. Gamma irradiation significantly improved the microbiological quality of DML. A minimum irradiation dose of $5 \mathrm{kGy}$ is recommended to enhance the quality of dried moringa leaves to meet standards of domestic and export markets.
\end{abstract}

Keywords: Drying Methods, Microbiological Quality, Moringa Leaves, Irradiation

\section{Introduction}

Moringa products are obtained from the plant Moringa oleifera. This is a rapidly-growing tree widely cultivated in most parts of the tropics. Moringa oleifera has many uses, including utilisation as animal forage, domestic cleaning agent, fertilizer, foliar nutrient, green manure, honey and sugar cane juice-clarifier, medicine, bio-pesticide and water purifier [1]. In recent times moringa products have been advocated as outstanding indigenous sources of highly digestible protein, $\mathrm{Ca}, \mathrm{Fe}$, Vitamin $\mathrm{C}$, and carotenoids suitable for utilization in many developing countries; and therefore have been used to combat malnutrition, especially among infants and nursing mothers [2, 3, 4]. Studies have also shown moringa products as having antibiotic, anti-trypanosomal, hypotensive, anti-spasmodic, anti-ulcer, anti-inflammatory, hypo-cholesterolemic, and hypoglycemic activities [5, 6, 7, 8, 9].

Currently, the production of moringa products in Ghana is largely a cottage industry characterized by small scale productions. Although national standards have been recently developed [10], the overall production, processing and packaging of moringa products lacks adequate regulation. The code of practice for the production of moringa products in the country [11] strongly recommends effective drying to reduce moisture content to less than $10 \%$. However, since the products easily attracts and reabsorbs moisture during milling and storage, contamination with moulds and other potential pathogens is a serious concern. In Ghana, other parts of West Africa and elsewhere, studies on herbal products in general have identified contaminants that present serious health hazards such as Salmonella, Escherichia coli, Staphylococcus aureus, Shigella spp and other Gram positive and Gram negative strains of bacteria [12, 13, 14, 15, $16,17]$.

Decontamination of dried herbal and food products have been achieved over the years using methods such as fumigation with ethylene/propylene oxide, ozone, irradiation and saturated steam [18, 19, 20, 21]. With the 
exception of irradiation, these procedures are increasingly becoming unacceptable because they result in losses of colour, flavour and aroma properties as well as deposit chemical residues in various products. Several studies have proved gamma irradiation as an effective decontaminating process that also preserves the sensory and organoleptic qualities of the products [22, 23, 24].

The objectives of this study were to:

i. assess the microbiological quality of retailed dried moringa leaves,

ii. assess the effect of drying methods (mechanical, solar and room drying) on the microbiological quality of moringa leaves,

iii. assess the effect of gamma irradiation on the microbiological quality of moringa leaves dried by the methods of mechanical, solar and room drying.

\section{Materials and Methods}

\subsection{Samples}

Dried moringa leaves (DML) used for the study were obtained from the Food Research Institute, Accra. Retail samples of DML were obtained from 6 different retail outlets in Accra.

\subsection{Drying}

Moringa leaves were dried by 3 methods at the Food Research Institute. Mechanical drying was undertaken using electric hot-air dryers at a temperature of $50^{\circ} \mathrm{C}$ for 30 minutes. Solar drying was undertaken by drying the leaves in a solar dryer at a temperature range of $35^{\circ} \mathrm{C}-55^{\circ} \mathrm{C}$ for 4 hours. Room drying was undertaken by drying the leaves at ambient temperatures $\left(28-32^{\circ} \mathrm{C}\right)$ for 4 days.

\subsection{Irradiation}

Samples of DML were sealed in polyethylene pouches and exposed to gamma-radiation doses of $0,2.5,5.0,7.5$ and 10.0 kGy using a Cobalt-60 source at the Radiation Technology Centre of Ghana Atomic Energy Commission. The dose rate of the irradiation process was $2.50 \mathrm{kGy} / \mathrm{hr}$ and the absorbed dose was confirmed by Fricke's dosimetry.

\subsection{Microbiological Analysis}

Samples were analysed for total viable cells, coliforms, moulds and yeasts, Escherichia coli, Salmonella spp. and Pseudomonas spp. by using the methods of serial dilution and pour plating [25]. Ten grams of each samples was added to $90-\mathrm{ml}$ peptone water $(1 \%$ peptone $+0.5 \% \mathrm{NaCl})$ and placed on a mechanical shaker (Junior Orbital Shaker, Lab-line Instruments, USA) for 15 minutes. The mixture was then allowed to settle for about 5 minutes to allow coarse material to settle down. Microbial load determination was carried out on the supernatant by using serial dilution and pour plate methods. Total viable cells were estimated on Plate count agar (Oxoid, UK) at $37^{\circ} \mathrm{C}$ for $48 \mathrm{hrs}$, colifoms on Violet red bile agar (Oxoid, UK) at $37^{\circ} \mathrm{C}$ for $48 \mathrm{hrs}$. Escherichia coli was estimated on Eosin Methlyene Blue Agar (Oxoid, UK) at $37^{\circ} \mathrm{C}$ for $48 \mathrm{hrs}$. Pseudomonas spp. was enumerated on Pseudomonas Agar Base and C-N Supplement (Oxoid, UK) at $37^{\circ} \mathrm{C}$ for $48 \mathrm{hrs}$. Moulds and yeast were estimated on oxytetracycline glucose yeast extract agar (Oxoid, UK) with incubation at $28^{\circ} \mathrm{C}$ for 48 hours. The presence of Salmonella spp. was shown by plating on Xylose Lysine Deoxycholate Agar (Difco, USA) with incubation at $37^{0} \mathrm{C}$ for 48 hours. For each sample, duplicate plating was carried out. Three independent experiments were conducted.

\subsection{Data Analysis}

The microbial counts (colony forming units, cfu/g) were transformed into logarithms $\left(\log _{10}\right)$ and means were determined.

\section{Results and discussion}

\subsection{Microbiological Quality of Retailed Dried Moringa Leaves}

The range of mean counts of total viable cells, coliforms, moulds and yeasts, E. coli and Pseudomonas spp. of the retail samples of DML were respectively $5.92-8.44,4.85-$ $7.25,1.65-3.69,3.71-4.78$ and $1.84-4.22 \log _{10} \mathrm{cfu} / \mathrm{g}$ (Table 1). Salmonella spp. was detected 2 out of the 6 samples analysed.

Whiles International standards require that total aerobic bacteria and fungi should not exceed $10^{4}$ and $10^{2} \mathrm{cfu} / \mathrm{g}$

Table 1. Microbiological profile of retail samples of dried moringa leaves.

\begin{tabular}{|c|c|c|c|c|c|c|}
\hline Samples & $\begin{array}{c}\text { Total viable } \\
\text { Count }\end{array}$ & Coliforms & $\begin{array}{c}\text { Moulds and } \\
\text { Yeasts }\end{array}$ & E. coli & Pseudomonas sp & Salmonella sp \\
\hline 1 & ${ }^{\mathrm{a}} 6.28 \pm 1.46$ & $6.20 \pm 0.64$ & $3.69 \pm 0.22$ & $4.56 \pm 0.08$ & $2.67 \pm 0.32$ & $\mathrm{~b}+$ \\
\hline 2 & $5.92 \pm 0.61$ & $4.85 \pm 0.18$ & $1.95 \pm 0.04$ & $3.72 \pm 0.32$ & $1.84 \pm 0.04$ & ${ }^{\mathrm{c}} \mathrm{ND}$ \\
\hline 3 & $8.44 \pm 1.48$ & $5.59 \pm 1.21$ & $1.65 \pm 0.21$ & $4.78 \pm 0.61$ & $4.22 \pm 0.44$ & ND \\
\hline 4 & $6.83 \pm 1.41$ & $7.25 \pm 1.12$ & $2.08 \pm 0.04$ & $4.72 \pm 0.22$ & $2.46 \pm 0.04$ & + \\
\hline 5 & $7.54 \pm 1.55$ & $5.36 \pm 0.82$ & $2.61 \pm 0.04$ & $3.92 \pm 0.22$ & $3.58 \pm 0.41$ & ND \\
\hline 6 & $6.69 \pm 1.24$ & $6.95 \pm 0.82$ & $3.56 \pm 0.08$ & $3.88 \pm 0.16$ & $3.15 \pm 0.14$ & ND \\
\hline
\end{tabular}

${ }^{\mathrm{a}}$ mean $\left(\log _{10} \mathrm{cfu} / \mathrm{g}\right) \pm \mathrm{SD}(\mathrm{n}=3),{ }^{\mathrm{b}}+=$ detected, ${ }^{\mathrm{c}} \mathrm{ND}=$ not detected

respectively [26], recently developed domestic standards for moringa products in Ghana require the acceptable counts of total viable cells to be $\leq 1.0 \times 10^{2} \mathrm{cfu} / \mathrm{g}$ and that of moulds and yeasts to be $\leq 5.0 \times 10 \mathrm{cfu} / \mathrm{g}$ [10]. In this study, all the retail 
samples of dried moringa leaves (DML) had mean counts of total viable cells and moulds and yeasts in excess of both domestic and international standards. Counts of coliforms, Pseudomonas spp and E .coli spp were also relatively high and the presence of Salmonella spp. in some of the samples of DML indicates unacceptable microbiological quality. Like most herbal products, dried moringa products are prone to contamination by microorganisms from the soil, the droppings of insects and birds which adhere to the leaves and stems of the plant before harvest and from the environment, water and handlers during drying. In addition to this, contamination could have been facilitated by prolonged drying of the leaves in shade to prevent loss of vitamins and other essential nutrients as recommended by the national code of practice [11].

\subsection{Effect of Drying Method on the Microbiological Quality of Moringa Leaves}

Samples of room-dried moringa leaves relatively had high counts of total viable cells (6.45); coliforms (6.18); moulds and yeasts (3.46); E. coli (1.58) and Pseudomonas spp. (3.32) compared to samples dried by mechanical or solar methods (Table 2). The corresponding counts for mechanically-dried moringa leaves were; total viable cells (3.12); coliforms (0.56); moulds and yeasts (2.66) whiles E. coli and Pseudomonas spp. were not detected. In the case of solar-dried moringa leaves, the counts were; total viable cells (2.61), whiles coliforms, moulds and yeasts, E. coli as well as Pseudomonas spp. were not detected. Salmonella spp. was also not detected in all the samples of DML (Table 2).

The processing of DML involves important steps such as washing, draining and drying which together ensure acceptable product quality. The process of drying (to $<10 \%$ moisture content) is therefore a critical step which prevents the proliferation of moulds and bacteria as well as other contaminating organisms. According to local and international codes of practice, 3 drying methods are recommended for processing moringa products depending on the scale of production and availability of resources. Whiles mechanical drying is recommended for large scale production, room drying is suitable for small scale production. Solar drying is recommended for both small and large scale production or in instances where electricity is unavailable.

The results show that room-dried moringa leaves had relatively higher counts of total viable cells, coliforms; moulds and yeasts, as well as E. coli and Pseudomonas spp. compared to mechanically or solar-dried moringa leaves. This observation could be due to contamination by microorganisms during the relatively longer period (4-6 days) for room drying. It is also important to note that the temperature of room drying $\left(28-32^{\circ} \mathrm{C}\right)$ is lower than those of mechanical drying $\left(50-55^{\circ} \mathrm{C}\right)$ and solar drying $\left(35-55^{\circ} \mathrm{C}\right)$, thus increasing the available moisture that could have supported microbial growth. Despite these limitations, most producers of moringa products continue to utilize room drying because of the leaching of nutrients associated with mechanical and solar drying methods. It is however important to note that solar-dried moringa leaves had a relatively better microbiological quality compared to mechanically-dried leaves. This observation might probably be due to the longer duration of exposure ( $4 \mathrm{hrs}$ ) of the solar-dried leaves compared to that of mechanically-dried leaves $(30 \mathrm{~min})$ as recommended by the code of practice [11].

\subsection{Effect of Irradiation on the Microbiological Quality of Dried Moringa Leaves}

As shown in Tables 3-7, gamma radiation dose of $2.5 \mathrm{kGy}$ reduced the count of total viable cells to $\leq 3.57$; coliform to $\leq 2.61$; moulds and yeasts to $\leq 2.61$ and eliminated all Pseudomonas spp and E. coli. Doses of 5, 7.5 and $10 \mathrm{kGy}$ eliminated all total viable cells, coliforms, moulds and yeasts, as well as Pseudomonas spp and E. coli from all the samples of mechanical, solar and room-dried moringa leaves.

Irradiation at a dose of $2.5 \mathrm{kGy}$ reduced the counts of total viable cells to $\leq 3.57 \log _{10}$ (Table 3 ). In a previous study, an irradiation dose of $2.5 \mathrm{kGy}$ reduced the count of total viable cells in moringa seed powder to $1.3 \times 10^{4} \mathrm{cfu} / \mathrm{g}$ [27]. No microorganisms were detected in all samples of mechanical, solar and room-dried moringa leaves after gamma irradiation at doses of 5, 7.5 and $10 \mathrm{kGy}$. These findings are to be expected since gamma irradiation has been shown to be generally effective in reducing the microbial load of dehydrated ingredients, spices and dried herbal products [22, 28]. Therefore, in order to meet national and international standards, irradiation should be integrated into processing protocols of moringa products in the country. It is accordingly recommended that DML should be irradiated at a minimum dose of $5 \mathrm{kGy}$ to ensure acceptable microbiological quality for both domestic and export markets. It is important to further note that gamma irradiation overcomes shortcomings such as chemical residues, loss of heat-sensitive active ingredients and discoloration associated with conventional technologies such as the use of chemical preservatives, heat, fumigants [29].

Table 2. Microbiological counts of moringa leaves produced by mechanical, solar and room drying methods.

\begin{tabular}{ccccc}
\hline Drying method & $\begin{array}{c}\text { Total viable } \\
\text { Count }\end{array}$ & Coliforms & $\begin{array}{c}\text { Moulds and } \\
\text { Yeasts }\end{array}$ & E. coli \\
\hline Mechanically-dried & $3.12 \pm 0.83$ & $0.56 \pm 0.34$ & $2.66 \pm 0.16$ & ND \\
Solar-dried & $2.61 \pm 0.42$ & ND & ND & ND \\
Room-dried & $6.45 \pm 0.35$ & $6.18 \pm 0.08$ & $3.46 \pm 0.45$ & ND \\
\hline
\end{tabular}

${ }^{\mathrm{a}}$ mean $(\log 10 \mathrm{cfu} / \mathrm{g}) \pm \mathrm{SD}(\mathrm{n}=3),{ }^{\mathrm{b}} \mathrm{ND}=$ not detected 
Abraham Adu-Gyamfi and Tahiru Mahami: Effect of Drying Method and Irradiation on the Microbiological Quality of Moringa Leaves

Table 3. Microbiological counts of total viable cells of dried moringa leaves before and after gamma irradiation.

\begin{tabular}{|c|c|c|c|c|c|}
\hline \multirow{2}{*}{ Drying method } & \multicolumn{5}{|c|}{ Dose (kGy) } \\
\hline & 0 kGy & $2.5 \mathrm{kGy}$ & 5.0 kGy & $7.5 \mathrm{kGy}$ & 10 kGy \\
\hline Mechanically-dried & a $3.20 \pm 1.41$ & ${ }^{\mathrm{b}} \mathrm{ND}$ & ND & ND & ND \\
\hline Solar-dried & $3.76 \pm 1.19$ & $2.36 \pm 0.18$ & ND & ND & ND \\
\hline Room-dried & $6.20 \pm 0.42$ & $3.57 \pm 0.04$ & ND & ND & ND \\
\hline
\end{tabular}

${ }^{\mathrm{a}}$ mean $(\log 10 \mathrm{cfu} / \mathrm{g}) \pm \mathrm{SD}(\mathrm{n}=3),{ }^{\mathrm{b}} \mathrm{ND}=$ not detected

Table 4. Microbiological counts of coliforms of dried moringa leaves before and after gamma irradiation.

\begin{tabular}{|c|c|c|c|c|c|}
\hline \multirow{2}{*}{ Drying method } & \multicolumn{5}{|c|}{ Dose (kGy) } \\
\hline & 0 kGy & $2.5 \mathrm{kGy}$ & $5.0 \mathrm{kGy}$ & $7.5 \mathrm{kGy}$ & $10 \mathrm{~Gy}$ \\
\hline Mechanically-dried & ${ }^{\mathrm{a}} 0.49 \pm 0.86$ & ${ }^{\mathrm{b}} \mathrm{ND}$ & ND & ND & ND \\
\hline Solar-dried & ND & ND & ND & ND & ND \\
\hline Room-dried & $6.83 \pm 0.06$ & $2.61 \pm 0.08$ & ND & ND & ND \\
\hline
\end{tabular}

${ }^{\mathrm{a}}$ mean $(\log 10 \mathrm{cfu} / \mathrm{g}) \pm \mathrm{SD}(\mathrm{n}=3),{ }^{\mathrm{b}} \mathrm{ND}=$ not detected

Table 5. Microbiological counts of moulds and yeasts of dried moringa leaves before and after gamma irradiation.

\begin{tabular}{|c|c|c|c|c|c|}
\hline \multirow{2}{*}{ Drying method } & \multicolumn{5}{|c|}{ Dose (kGy) } \\
\hline & 0 kGy & $2.5 \mathrm{kGy}$ & $5.0 \mathrm{kGy}$ & $7.5 \mathrm{kGy}$ & $10 \mathrm{kGy}$ \\
\hline Mechanically-dried & ${ }^{\mathrm{a}} 2.63 \pm 0.19$ & ${ }^{b} \mathrm{ND}$ & ND & ND & ND \\
\hline Solar-dried & ND & ND & ND & ND & ND \\
\hline Room-dried & $2.99 \pm 0.65$ & $2.61 \pm 0.07$ & ND & ND & ND \\
\hline
\end{tabular}

${ }^{\mathrm{a}}$ mean $(\log 10 \mathrm{cfu} / \mathrm{g}) \pm \mathrm{SD}(\mathrm{n}=3),{ }^{\mathrm{b}} \mathrm{ND}=$ not detected

Table 6. Microbiological counts of Pseudomonas spp. of dried moringa leaves before and after gamma irradiation.

\begin{tabular}{|c|c|c|c|c|c|}
\hline \multirow{2}{*}{ Drying method } & \multicolumn{5}{|c|}{ Dose (kGy) } \\
\hline & 0 kGy & $2.5 \mathrm{kGy}$ & $5.0 \mathrm{kGy}$ & $7.5 \mathrm{kGy}$ & 10 kGy \\
\hline Mechanically-dried & ${ }^{\mathrm{b}} \mathrm{ND}$ & ND & ND & ND & ND \\
\hline Solar-dried & ND & ND & ND & ND & ND \\
\hline Room-dried & ${ }^{\mathrm{a}} 3.52 \pm 0.21$ & ND & ND & ND & ND \\
\hline
\end{tabular}

${ }^{\mathrm{a}}$ mean $\left(\log _{10} \mathrm{cfu} / \mathrm{g}\right) \pm \mathrm{SD}(\mathrm{n}=3),{ }^{\mathrm{b}} \mathrm{ND}=$ not detected

Table 7. Microbiological counts of E coli of dried moringa leaves before and after gamma irradiation.

\begin{tabular}{|c|c|c|c|c|c|}
\hline \multirow{2}{*}{ Dryingmethod } & \multicolumn{5}{|c|}{ Dose(kGy) } \\
\hline & 0kGy & $2.5 \mathrm{kGy}$ & $5.0 \mathrm{kGy}$ & $7.5 \mathrm{kGy}$ & $10 \mathrm{kGy}$ \\
\hline Mechanically-dried & ${ }^{\mathrm{b}} \mathrm{ND}$ & ND & ND & ND & ND \\
\hline Solar-dried & ${ }^{\mathrm{a}} 0.72 \pm 0.15$ & ND & ND & ND & ND \\
\hline Room-dried & $1.34 \pm 0.21$ & ND & ND & ND & ND \\
\hline
\end{tabular}

${ }^{\mathrm{a}}$ mean $\left(\log _{10} \mathrm{cfu} / \mathrm{g}\right) \pm \mathrm{SD}(\mathrm{n}=3),{ }^{\mathrm{b}} \mathrm{ND}=$ not detected

\section{Conclusion}

Microbiological quality of most dried moringa leaves retailed in Accra does not meet domestic and international standards. Mechanical or solar methods of drying moringa leaves improved the microbiological quality to a greater extent compared to room drying. However, the microbiological quality of solar-dried moringa leaves was superior to that of mechanically-dried leaves. Gamma irradiation significantly improved the microbiological quality of dried moringa leaves. A minimum irradiation dose of $5 \mathrm{kGy}$ is recommended to enhance the quality of dried 
moringa leaves to meet standards of domestic and export markets.

\section{Acknowledgements}

We wish to express our profound gratitude to all technicians, technologists, trainees and national service personnel of Radiation Technology Centre of the Ghana Atomic Energy Commission.

\section{References}

[1] Fuglie, L. J. (1999) The Miracle Tree: Moringa oleifera: Natural Nutrition for the Tropics. Church World Service, Da kar. 68 pp.; revised in 2001 and published as The Miracle Tree: The Multiple Attributes of Moringa, $172 \mathrm{pp}$. http://www.echotech.org/bookstore/advanced_search_result. php?keywords $=$ Miracle + Tree

[2] Babu, S. C. (2000) Rural nutrition interventions with indig enous plant foods: a case study of vitamin deficiency in Malawi. International Food Policy Research Institute, Washington,DC. Biotechnology, Agronomy Soc. Environ. 4(3):169-179.URL:

http://www.bib.fsagx.ac.be/library/base/text/v4n3/169.pdf.

[3] D’Souza, J. and Kulkarni, A.R. (1993) Comparative stud ies on nutritive values of tender foliage of seedlings and mature plants of Moringa oleifera Lam. Journal of Economic and Taxonomic Botany 17(2): 479-485.

[4] Freiberger, C. E. and Vanderjagt, D. J. (1998) Nutrient con tent of the edible leaves of seven wild plants from Niger. Plant Foods for Human Nutrition 53(1): 57-69.

[5] Bharali R., Tabassum, J. and Azad, M. R. J. (2003) Chemomodulatory effect of Moringa oleifera, Lam, on hepatic carcinogen metabolizing enzymes, antioxidant parameters and skin papillomagenesis in mice. Asian Pacific Journal of Cancer Prevention 4: 131-139.

[6] Caceres A, Saravia, A., Rizzo, S., Zabala, L. De Leon, E., Nave, F. (1992) Pharmacologic properties of Moringa oleifera. 2: Screening for antispasmodic, anti inflammatory and diuretic activity. Journal of Ethnopharmacology 36: 233-237.

[7] Caceres, A., Cabrera, O., Morales, O., Mollinedo, P. and Mendia, P. (1991) Pharmacological properties of Moringa oleifera. 1: Preliminary screening for antimicrobial activity. Journal of Ethnopharmacology 33: 213-216.

[8] Gupta M, Mazumder, U. K. (1997) Anti-epileptic and anti-cancer activity of some indigenous plants. Indian Journal of Physiology and Allied Sciences 51(2): 53-56.

[9] Haristoy X, Fahey, J. W. Scholtus, I and Lozniewski, A (2005) Evaluation of antimicrobial effect of several isothiocyanates on Helicobacter pylori. Planta Medica 71: 326-330.

[10] GS 998:2009, Medicinal Plants - Moringa leaf products, Ghana Standards Authority

[11] GS 999:2000, Medicinal Plants - Production of Moringa Leaf Products, Ghana Standards Authority.
[12] E. Owusu, G.T. Odamtten (1999) Quality of Ghana Herbal Tea: Microflora and Control Measures, Journal of the Ghana Science Association Volume 1 Number 3,pp. 84-99

[13] Arias, M. L., Chaves, C., Alfaro, D. (1999) Microbiological analysis of some herbal infusions used as medicines. Rev Biomed.10(1):1-6.,

http://www.imbiomed.com.max/uay.English/ZYu91-01.html Erich, C., Wolfgang, K., Brigitte, K. (2001) Microbiologi cal Status of Commercially available Medicinal Herbal Drugs-A screenings study. Planta Med. 67:263-269.

[14] Wolfgang ,K,. Erich, C., Brigitte, K. ( 2002) Microbial con tamination of medicinal plants- A review. Planta Medica. 2002;68:5-15.

[15] Adeleye, I. A., Okogi, G, Ojo, E. O. (2005) Microbial contamination of herbal preparations in Lagos, Nigeria. $J$. Health, Population and Nutrition. 23(3):296-297.

[16] Okunlola, A., Adewoyin, A.B., Odeku, A.O. (2007) Eval uation of pharmaceutical and microbial qualities of some herbal medicinal products in south western Nigeria. Trop $J$. Pharmaceut Res.6(1):661-670.

[17] Gerphart, U. (1990). Kontamination der Gewurze. pp. 89 126. In Gewurze in der Lebensmittelindustrie. Behr's Verlag, Hamburg, Germany. Cited in: Kneifel, W. and Berger, E. (1994). Microbiological Criteria of Random Samples of Spices and Herbs Retailed on the Austrian Market. J. Food Prot., vol. 57, No. 10. pp 893 - 901.

[18] Zagon, J.; Dehne, L.I.; Wirz, J., Binke, B and Bogl, K.W. (1992). Ozon-Behandlung zur Entkeimung von Gewurzen. Bundesgesundheitsblatt 35:20-23. Cited in: Kneifel, W and Berger, E. (1994). Microbiological Criteria of Random Samples of Spices and Herbs Retailed on the Austrian Mar ket. J. of Food Prot, vol. 57, No. 10. pp 893 - 901.

[19] Brulhart, M.; Gysel, M. and Emch, F. (1986). Das Dampfsterilisieren von Gewurzen. Food Sci. Technol. 19: 405 - 406 Cited in: Kneifel, W. and Berger, E. (1994). Microbiological Criteria of Random Samples of Spices and Herbs Retailed on the Austrian Market. J. of Food Prot. vol. 57, No. 10. pp 893 - 901.

[20] Sharma, A., Padwal-Desai, S.R. and Nair, P. M. (1989). Assessment of Microbiological Quality of Some Gamma Irradiated Indian Spices. J. Food Sci. 54: 489 - 490.

[21] Farkas, J. (1988). Irradiation of Dry Food Ingredients, CRC Press, Boca Raton, Fla., pp. 42.

[22] Council for Agricultural Science and Technology (CAST). Radiation Pasteurisation of Food, Issue Paper No. 7, CAST, Ames, IA (1996).

[23] IAEA-TECDOC-639 (1992), International Atomic Energy Agency, Vienna-ISSN 1011- 4289

[24] American Society for Testing and Materials. (1998). Stand ard Guide for Irradiation of Spices, Herbs and Vegetable Seasoning to Control Pathogens and other Microorganisms. ASTM Standard F 1885-98.

[25] APHA (1976). Compendium of Methods for the Microbi ological Examination of Foods. Speck, M.K (ed) Ameri can Public Health Association, Washington, D.C.

[26] UNIDO (1984) Guidelines for commercial plantation and manufacture of medicinal and aromatic plants 
[27] A. Adu-Gyamfi, V. Appiah and J. Nketsia-Tabiri (2014) Preliminary Studies on Decontamination of Some Dried Herbal Products by Gamma Irradiation.' Journal of Medicinal Plant Research, Vol. 8(2), pp. 116-120

[28] Adu-Gyamfi, A. (2005). Effect of Storage Time on the
Microbial Quality of Some Spices and Dried Seasonings. Ghana Journal of Agricultural Science, 39, 93-101.

[29] Farkas, J. (1998) Irradiation as a method for decontaminating food: A review International Journal of Food Microbiology 44 (1998) 189-204. 